\title{
Do Population Density, Socio-Economic Ranking and Gini Index of Cities Influence Infection Rates from Coronavirus? Israel as a case Study
}

Yuval Arbel ( $\nabla$ yuval.arbel@gmail.com )

Western Galilee College https://orcid.org/0000-0003-4365-6280

Chaim Fialkoff

Hebrew University of Jerusalem

Amichai Kerner

Netanya Academic College

Miryam Kerner

Technion, Israel Institute of Technology

\section{Research Article}

Keywords: COVID-19, Population Density, Socio-Economic Ranking, Gini Index, Rank-Size Rule

Posted Date: July 8th, 2020

DOI: https://doi.org/10.21203/rs.3.rs-40387/v1

License: (9) This work is licensed under a Creative Commons Attribution 4.0 International License.

Read Full License

Version of Record: A version of this preprint was published at The Annals of Regional Science on August 29th, 2021. See the published version at https://doi.org/10.1007/s00168-021-01073-y. 


\title{
Do Population DenSity, Socio-Economic RANKING AND Gini INDEX OF CITIES INFLUENCE INFECTION RATES FROM CORONAVIRUS? ISRAEL AS A CASE STUDY
}

\author{
Yuval Arbel, ${ }^{a}$ Chaim Fialkoff, and Amichai Kerner, and Miryam Kerner*
}

\begin{abstract}
A prominent characteristic of the COVID-19 pandemic is the marked geographic variation in COVID-19 prevalence. The objective of the current study is assess the influence of population density and socio-economic measures (socio-economic ranking and the Gini index) across cities on coronavirus infection rates. Israel provides an interesting case study based on the highly nonuniform distribution of urban populations, the existence of one of the most densely populated cities in the world and diversified populations. The outcomes of our study show that ceteris paribus, projected probabilities to be infected from coronavirus rise with higher population density and Gini coefficients and drop with higher socio-economic ranking of the city. Moreover, when measured by identical units of standard deviations, the contribution of the socio-economic measure is the highest. Findings thus provide a tool to city and public health planners in an effort to address the spatial and socio-economic aspects of the pandemic. Compared with wealthier cities, poorer and denser cities should employ more pre-emptive measures to better enable the early identification of the incidence of COVID-19 in these cities. Finally, from a public health perspective, a densly populated city with a low socio-economic ranking and high income inequality requires immediate intervention in order to mitigate the dissemination of the virus.
\end{abstract}

Key Words: COVID-19; Population Density; Socio-Economic Ranking; Gini Index; Rank-Size Rule

Current Version: July 8, 2020

JEL Codes: H75, I14, R12

${ }^{\text {a }}$ Corresponding Author

* Yuval Arbel, Sir Harry Solomon School of Economics and Management, Western Galilee College, Acre 2412101, Israel, email: YuvalAr@wgalil.ac.il; yuval.arbel@gmail.com ; Chaim Fialkoff, Institute of Urban and Regional Studies, Hebrew University of Jerusalem, Mt. Scopus, Jerusalem, 9190501; email: cfialk@gmail.com. Amichai Kerner, School of Real Estate, Netanya Academic College, 1 University Street, Netanya 4223587, Israel, email: kerneram@netvision.net.il. Miryam Kerner, the Ruth and Bruce Rappaport Faculty of Medicine, Technion, Israel Institute of Technology. Email: Miryamke@ @lalit.org.il. The authors are grateful to Yifat Arbel, Nissim Ben David (the president) and the participants at the "light at the end of the corona tunnel" zoom meeting in Western Galilee College for helpful comments. 


\section{INTRODUCTION}

Coronavirus 2019 (COVID-19) is a declared global pandemic with multiple risk factors (WHO report: coronavirus). A prominent characteristic of the pandemic is the marked geographic variation in COVID-19 prevalence. As of March 2020, several countries - the epicenters of the pandemic - were already badly affected by the pandemic, while others had just confirmed the first few cases. Balsius (2020) attributes this epidemic prevalence to the power law distirbution (e.g., Newman, 2005), namely, the correlation between the arrival time of the disease and the COVID19 prevalence.

Given this geographic variation, it is of interest to examine whether and to what extent infection rates within countries are influenced by differences in urban population densities and socio-economic conditions. Schmitt-Grohé et al. (2020) found no correlation between access to Covid-19 testing and the level of income in New York City. The ten percent of the city's population living in the richest zip codes with 29 percent of the city's income received 11 percent of the Covid19 tests. The ten percent of the city's population living in the poorest zip codes with only four percent of the city's income, received ten percent of the tests. On the other hand, Clarke and Whitely (2020) argue that economic inequality can help predict COVID19 deaths in the US. Other important factors the authors mention are population densities: "Population density matters as well since inter-personal transmission of the virus will be higher in densely populated areas".

The objective of the current study is assess the influence of these two factors (population density and socio-economic measures $)^{1}$ on coronavirus infection rates - the ratio between the number of infected persons to the total city population. These data are calculated based on the

\footnotetext{
${ }^{1}$ For the definition of socio-economic measure see, for example, ICBS: Characterization and Classification of Geographical Units by the Socio-Economic Level of the Population, 2015. Available at: https://www.cbs.gov.il/en/publications/Pages/2019/Characterization-and-Classification-of-Geographical-Units-bythe-Socio-Economic-Level-of-the-Population-2015.aspx
} 
Israeli Ministry of Health report, which is updated as of May 11, 2020. Population densities, socioeconomic measures and the Gini index updated to 2018 are based on the Israel Central Bureau of Statistics (CBS) reports. Given the highly non-uniform distribution of population across cities, the existence of one of the most densly populated cities in the world (Bnei Brak) and diversified populations, Israel provides an interesting case study to explore this hypothesis.

The outcomes of our study show that ceteris paribus, projected probabilities to be infected from coronavirus rise with higher population density and Gini index and drop with higher socioeconomic ranking of the city. Moreover, when measured by identical units of standard deviations, the contribution of the socio-economic measure is the highest. In an effort to preserve identical infection rates, one standard deviation rise in the city's socio-economic ranking is equivalent to 1.6654 standard deviation drop in the population density and1.8779 standard deviation drop in the Gini index.

The remainder of this study is organized as follows. Section 2 reports the beackground and descriptive statistics. Section 3 describes the methodology and section 4 reports the results. Finally, Section 5 concludes and summarizes.

\section{BACKGROUND AND DESCRIPTIVE STATISTICS}

\section{(2a) Background}

Based on the information reported in Appendix B and following Alperovich (1984) and O'Sullivan (2012: 81-82), we ran a rank-size rule test for the 95 Israeli cities. ${ }^{2}$ The conventional empirical model for such a test is given by the following equation:

$$
G(P)=A P^{-\alpha}
$$

\footnotetext{
${ }^{2}$ To the best of our knowledge, this is the first time such a test is carried out under the Israeli setting.
} 
Where $G(P)=$ number of cities with population $P$ or more; $P=$ population of city; $A=$ constant term; $\alpha=$ Pareto exponent. This parameter has important implications in terms of population distribution across cities. As this parameter becomes lower, populations are less evenly distributed across cities. Given more populated and denser cities, one would anticipate a higher coronavirus spread with lower values of $\alpha$.

The estimation results of equation (1) for the entire population of 255 cities yield:

$$
\operatorname{proj}[\ln (G(P))]=12.48522-0.8173233 \ln (P) ; \quad R^{2}=0.9053
$$

$$
(0.1623) \quad(0.0166157)
$$

As anticipated, estimation of $\alpha$ is low, and the null hypothesis $\alpha=1$ is clearly rejected (99\% confidence interval of $[0.7742,0.8604])$. In his meta analysis, Nitsch (2005) found that in most studies this parameter is above 1.0. As suggested by the strict interpretation of the Zip's law, the implication might be a departure from uniform distribution of population across cities in Israel.

The conditions that fully satisfy the rank-size rule according to which the product $P \cdot G(P)$ equals $P_{M A X}$, the population in the largest city (Jerusalem $-919,438$ inhabitants), are: 1) $\alpha=1$ and 2) $A=P_{M A X}$. For the entire population, both the separate and the joint hypotheses are clearly rejected (respective calculated $p$-values: $p=3.07 \cdot 10^{-23} ; p=3.515 \cdot 10^{-13}$ and $p=2.689$. $\left.10^{-85}\right)$

Given that our sample is restricted to 95 cities and towns with information about the socioeconomc and the Gini index for inequality, the estimation results of equation (1) for the sample of 95 cities and towns yield:

$$
\begin{aligned}
\operatorname{proj}[\ln (G(P))]= & 14.83515-1.042334 \ln (P) ; \quad R^{2}=0.9630 \\
& (0.2253791) \quad(0.0211988)
\end{aligned}
$$


where standard errors are given in parentheses. The first test supports the null hypothesis $\alpha=1$ at the $1 \%$ level $(p=0.0487)$. However, the null hypothesis $A=\ln (919,438)=13.731532$, and the joint hypothesis $\alpha=1$ and $A=13.731532$ are not supported empirically ( $p=3.8444 \cdot 10^{-6}$ and $p=$ $2.59 \cdot 10^{-48}$, respectively). Compared with the full sample, the Pareto efficiency parameter rises with the restriction of the sample. An analysis of the 160 omitted settlements (=255-95) shows that $83.75 \%$ of these settlements have population density lower than 3,000 persons per sq. km. Given the selection criteria for the sample (the exclusion of relatively small cities with unknown information regarding socio-economic measures and low infection rates), yielding higher Pareto efficiency parameter, the implication, which is tested directly in subsequent sections, might be that coronavirus spread is higher in denser cities.

\section{(2b) Descriptive Statistics}

Table 1 reports the descriptive statistics. The mean infected-population ratio in the 95 Israeli cities is 210.90 and the standard deviation is 233.64 per 100,000 persons in the city pouplation. Nazareth, an Arab city, located at the northern statistical region and the $20^{\text {th }}$ most pouplated in Israel with 77,064 inhabitants, is ranked as the city with the minimum rate of infected persons -24.65 per 100,000 persons. $^{3}$ Bnei Brak - an ultra-orthodox (Haredi) Jewish and the $9^{\text {th }}$ most populated city with the highest population density of 26,512 persons per square kilometer, exhibits the maximum rate of $1,463.32$ per 100,000 persons in the overall city population (INFECTED).

\footnotetext{
${ }^{3}$ In fact, the Arab sector, comprising of $20.7 \%$ of the overall Israeli population (Israel CBS: Israel in Figures, 2015) is considered highly succesfull in keeping low coronavirus infection rates, in spite of the high population densities in Arab cities.
} 
Referring to the population densities, the mean is 4,397 and the standard deviation is 4,223 persons per sq. km.. While Mizpe Ramon in the Negev exhibits the lowest population density of 67 persons per sq. km., Bnei Brak exhibits the maximum population density of 26,512 persons per sq. km. (POP_DENSITY). Bnei Brak is considered one of the densest cities in the world with higher population density than Kolkata, India (24,306 persons per sq. km. $)^{4}$ and similar to Portau-Prince, Haiti $\left(27,395\right.$ persons sq. km.) ${ }^{5}$ and Manhattan, New York (27,544 persons per sq. km.). ${ }^{6}$

Referring to the socio-economic ranking on a scale 1 (=the lowest) to 10 (=the highest), the mean rank is 5.01 and the standard deviation is 2.3497. Two ultra-orthodox cities (Modi'in Illit; Beitar Illit) and three Bedouin cities (Hura; Ar'ara (Negev); Rahat) exhibit the lowest socioeconomic ranking of 1. Interestingly, these cities display low population density levels (Hura 2,388; Ar'ara (Negev) - 1,217 and Rahat - 3,403 persons per sq. km). According to the OECD report from 2018: "However, the share of working poor has risen because many workers, notably Israeli-Arabs and Haredim, are in low-paid jobs due to their weak skill sets. Workers from these communities are often trapped in low quality jobs, implying persistent inequality and weak aggregate productivity. Moreover, low social transfers imply that the often large families in these communities face deprivation that contributes to child poverty. High house

\footnotetext{
${ }^{4}$ Source: Office of the Registrar General \& Census Commissioner, India: West Bangai.It should be noted, however, that while the overall population in Bnei Brak is 193,744 persons, the overall population in Kolkota is approximately 23 times higher $-4,496,694$ persons.

${ }^{5}$ Source: Institut Haitien De Statistique Et the Informatique (IHSI): "Mars 2015 Population Totale, Population de 18 Ans et Plus Menages et Densites Estimes En 2015, available at: https://web.archive.org/web/20151106110552/http://www.ihsi.ht/pdf/projection/Estimat_PopTotal_18ans_Menag20 15.pdf (last accessed at May 24, 2020). It should be noted, however, that while the overall population in Bnei-Berak is only 193,744 persons, the overall population in Porte-au-Prince is approximately fivefold higher - 987,310 persons.

${ }^{6}$ It should be noted, however, that while the overall population in Bnei-Berak is only 193,744 persons, the overall population in Manhatten is approximately 8 times higher - 1,628,701 persons.
} 
prices also weigh on the social situation and well-being. Without further policy action, these trends are likely to worsen, as Israeli-Arabs and Haredim will constitute half the population by 2059." (page 10). Two cities are ranked at the maximum 9th scale of the socio-economic measure (Ramat Hasharon; Shoham) and also exhibit respective low population densities of 2,768 and 2,903 persons per sq. km. (SOCIO_ECONOMIC).

Finally, the average Gini index across these 95 cities is 0.4099 and the standard deviation is quite low - 0.0422. Jisr az-Zarqa, an Arab village located at the Hadera sub-district exhibits both the lowest Gini coefficient of 0.2745 , as well as high population density of 8,944 persons per sq. $\mathrm{km}$. and a low social ranking of 2. Ramat Hasharon displays both the highest Gini index of 0.5167, as well as relatively low population density of 2,768 persons per sq. $\mathrm{km}$. and the maximum social ranking of $9($ GINI).

A simple regression analysis applied to the 95 cities and towns for which the socioeconomic measures are available demonstrates that:

$$
\operatorname{proj}(G I N I)=0.3481616+0.0123415 \text { SOCIO_ECONOMIC } ; \quad R^{2}=0.4722
$$$$
(0.00748) \quad(0.00135)
$$

where standard errors are given in parentheses. The implication is that the socio-economic index explains $47.22 \%$ of the variance of the Gini index and income inequality is expected to grow by 1.234 percent with each additional 1 unit increase in the socio-economic ranking of the city. ${ }^{7}$ As for the relationships between population density and each of these two measures, they are uncorrelated $(p=0.9223$ and $p=0.9698)$.

Figure 1 provides box plots of all the variables normalized to the same unit of measurements. The figure clearly demonstrates that while the distributions of the socio economic

\footnotetext{
${ }^{7}$ The $99 \%$ confidence interval is [0.00878, 0.015899].
} 
measures are symmetrical, the distributions of the rate of infection and population density are skewed to the right, namely, have a right tail. Moreover, compared to the socio-economic measures, the standard deviations of the infection rate and population density, namely, the dispersion of values around the mean, seem smaller.

\section{Methodology}

Consider the following fractional logit model (e.g., Papke and Wooldrige (1996); Johnston and Dinardo (1997): 424-426; Wooldrige (2010)) applied to 95 Israeli cities with at least 15 cases of coronavirus infections:

$\operatorname{Pr}(0<Y<1)=F\left(\hat{\alpha}_{0}+\hat{\alpha}_{1} X_{1}+\hat{\alpha}_{2} X_{2}+\hat{\alpha}_{3} X_{3}\right)$

where $\quad Y=$ INFECTED $=\frac{\text { CORONA_CASES }}{\text { POPULATION }} ; \quad X_{1}=$ POP_DENSITY $=\frac{\text { POPULATION }}{\text { KILOMETER }} ; \quad X_{2}=$ SOCIO_ECONOMIC; $X_{3}=$ GINI $; F\left(Y_{j}\right)=\frac{\exp (Y)}{1+\exp (Y)} ;$ OR $=\operatorname{proj}\left[\frac{p}{1-p}\right] ; \alpha_{0}, \alpha_{1}, \alpha_{2}, \alpha_{3}$ are parameters; and the cirumflex denotes estimated parameters.

The advantage of the fractional logit model lies in the fact that when transformed to projected probabilities, projections are bounded to be between 0 and 1 . The disadvantage lies in the difficulty to provide direct interpretation to the parameters. Consequently, we also estimate the following Linar Probability model (LPM, e.g., Johnston and Dinardo, 1997: ):

$Y=\alpha_{0}^{\prime}+\alpha_{1}^{\prime} X_{1}+\alpha_{2}^{\prime} X_{2}+\alpha_{3}^{\prime} X_{3}+\epsilon$

where $\alpha_{0}^{\prime}, \alpha_{1}^{\prime}, \alpha_{2}^{\prime}, \alpha_{3}^{\prime}$ are parameters and $\epsilon$ is the stochastic random disturbance term. 
In an effort to measure the relative contribution of each index to the rate of infection in identical standard deviation units, we run the following standardized beta coefficients regression (e.g., Schroeder et al., (1986): 31-32; Vittinghoff et. al., (2005): 75-76):

$$
\mathbb{Z}(Y)=\beta_{0}+\beta_{1} \mathbb{Z}\left(X_{1}\right)+\beta_{2} \mathbb{Z}\left(X_{2}\right)+\beta_{3} \mathbb{Z}\left(X_{3}\right)+\mu
$$

where $\mathbb{Z}(\cdot)$ is the standardized normal distribution transformation of each variable (e.g., $\mathbb{Z}\left(V_{i}\right)=$ $\frac{V_{i}-\bar{V}}{\sigma_{V}}$ for $i=1,2,3, \cdots, 95$ where $\bar{V}, \sigma_{V}$ are the respective mean and standard deviation of the variable $\left.V_{i}\right) ; \beta_{0}, \beta_{1}, \beta_{2}, \beta_{3}$ are the parameters reflecting the standardized beta coefficients, and $\mu$ is the classical random disturbance term

\section{RESULTS}

Table 1 reports the regression outcomes of equations (2)-(4). According to the outcomes reported in column (2), the three measures explain 39.8 percent of the variance of the dependent variable. Projected probability to be infected rises by $2.18 \cdot 10^{-7}$ following a one unit increase in the population density, where socio-economic and Gini coefficients remains unchanged $(p=$ $\left.5.21 \cdot 10^{-6}\right)$. Projected probability to be infected drops by $6.53 \cdot 10^{-4}$ following a one point increase in the socio-economic index, where population density and the Gini index remains unchanged $\left(p=7.30 \cdot 10^{-8}\right)$. Finally, projected probability to be infected rises by 1.93 percent following a shift from Gini index of zero (total equality) to one (total inequality), where population density and the socio-economic measure remains unchanged $\left(p=2.42 \cdot 10^{-3}\right)$.

The bottom of Table 1 reports the $\frac{1}{V I F}$ and VIF (Variance Inflation Factor) measures (e.g.,

Belsley, Kuh and Welsch, 2004). This is a measure for multicollinearity, where $\frac{1}{V I F}=1-R^{2}$ for the three regressions between POP_DENSITY, SOCIO_ECONOMIC and GINI as the dependent 
variables against the remaining independent variables. This measure indicates no severe multicollinearity between the two socio-economic measures. ${ }^{8}$

Figures 2, 3 and 4 are based on the regression outcomes given in coulmn (1) of Table (2). The vertical axis in each figure reflects the projected probability to be infected from the coronavirus disease after trasformation of the coefficients and their $95 \%$ confidence intervals. The horizonal axis in each figure is based on the on sample values of the variables. The figures present the rise of coronavirus infection rates from 157 to 64 per 100,000 persons with population density; the drop from 526 to 50 per 100,000 persons with socio-economic ranking and the rise from 102 to 769 per 100,000 persons with the Gini coefficient.

Based on equation (4) and column (3) in Table 1, in terms of coronavirus infected per 100,000 persons in the population, one standard deviation rise in the city's socio-economic ranking is equivalent to $\frac{0.656311}{0.3940823}=1.6654$ standard deviation drop in the population density. Moreover, one standard deviation rise in the city's economics and socio-economic ranking is equivalent to $\frac{0.656311}{0.3494891}=1.8779$ standard deviation drop in the Gini index.

Given that high population density represents tall structures, findings provide a tool to city planners in an effort to control viruses spreading. Compared with wealthier cities, poorer and denser cities should employ more pre-emptive measures to better enable the early identification of the incidence of COVID-19 in these cities

\footnotetext{
${ }^{8}$ The conventional measure of severe multicolinearity is VIF $\geq 10$, namely, $0.9 \leq R^{2} \leq 1.0$.
} 


\section{SUMMARY AND CONCLUSIONS}

Given the huge geographic variation in COVID-19 prevalence, the objective of the current study is assess the influence of population density and socio-economic measures on coronavirus infection rates - the ratio between the number of infected persons and the total city population. These are calculated based on the Israeli Ministry of Health report, which is updated to May 11, 2020. Population densities, socio-economic rankings and the Gini index updated to 2018 are based on the Israel CBS reports. Israel provides an interesting case study based on the highly non-uniform distribution of population across cities, the existence of one of the most densly populated cities in the world (Bnei Brak) and diversified populations.

The outcomes of our study show that ceteris paribus, projected probabilities to be infected from coronavirus rise with higher population density and Gini coefficient and drop with higher socio-economic ranking of the city. Moreover, when measured by identical units of standard deviations, the contribution of the socio-economic measure is the highest. In an effort to preserve identical infection rates, one standard deviation rise in the city's socio- economic ranking is equivalent to 1.6654 standard deviation drop in the population density and1.8779 standard deviation drop in the Gini index.

In the conventional urban economics texbooks, high population density represents multistory structures with smaller building footprints, where price of land is expensive (at the central cities, e.g., Mills and Hamilton 1989: 425-434; O’Sullivan 2012: 127-151; Arbel, Fialkoff and Kerner, 2019). Consequently, findings provide a tool to city planners in an effort to control viruses spreading. Compared with wealthier cities, poorer and denser cities should employ more preemptive measures to better enable the early identification of the incidence of COVID-19 in these cities. Finally, to decrease virus spreading, from a public health perspective, a densly populated 
city with low socio-economic ranking and high income inequality requires immediate intervention.

6. Conflict OF InTERESTS: All The authors declare there are no conflict of interests. This research is based on publicly available information. 


\section{REFERENCES}

Alperovich, Gershon (1984). The Size Distribution of Cities: On the Empirical Validity of the Rank-Size Rule. Journal of Urban Economics, 16: 232-239.

Arbel, Yuval, Fialkoff, Chaim and Amichai Kerner. The Chicken and Egg Problem: Obesity and the Urban Monocentric Model. Journal of Real Estate Finance and Economics (2019). https://doiorg.elib.openu.ac.il/10.1007/s11146-019-09737-5.

Belsley DA, Kuh E, Welsch RE. Regression Diagnostics: Identifying Influential Data and Sources of Collinearity. Hoboken, N.J.: Wiley-Inter science; 2004.

Blasius, Bernd. (2020). Power-law distribution in the number of confirmed COVID-19 cases. Available at: https://arxiv.org/pdf/2004.00940.pdf.

Clarke, Harold and Paul Whitely (2020). Economic Inequality Can Help Predict COVID19 Deaths in the US. Available at: https://blogs.lse.ac.uk/usappblog/2020/05/06/economic-inequality-canhelp-predict-covid-19-deaths-in-the-us/.

Gat, Daniel. Compact Hedonic Model of the Greater Tel Aviv Housing Market. Journal of Real Estate Literature, 1996, 4:2, 162-72.

Gat, Daniel. Urban Focal Points and Design Quality Influence Rents: The Case of the Tel Aviv Office Market. Journal of Real Estate Research, 1998, 16:2, 229-47.

Israel Central Bureau of Statistics. Israel in Figures, 2015: pages 3; 6. available at: https://www.cbs.gov.il/he/publications/DocLib/isr_in_n/isr_in_n15e.pdf (Last accessed at May 23, 2020).

Israel CBS: Statistical Abstract of Israel, 2019: Population Density per Square Kilometer. https://www.cbs.gov.il/he/publications/doclib/2019/2.shnatonpopulation/st02_23.pdf (Last accessed at May 23, 2020). 
Israel Central Bureau of Statistics. Characterization and Classification of Geographical Units by the Socio-Economic Level of the Population, 2015. Available at: https://www.cbs.gov.il/en/publications/Pages/2019/Characterization-and-Classification-ofGeographical-Units-by-the-Socio-Economic-Level-of-the-Population-2015.aspx

Johnston, Jack and John Dunardo. Econometric Methods, Fourth Edition. McGraw Hill International Edition (1997).

Mills, E. S., \& Hamilton, B. W. (1989). Urban Economics (4th ed., pp. 425-434). Appendix A: Simplified Mathematical Model of Urban Structure.

Newman, MEJ, 2005. Power laws, Pareto distributions and Zipf's law. Contemporary Physics, 46(5): $323-351$.

Nistsch, Volker (2005). Zipf zipped. Journal of Urban Economics 57 (2005) 86-100.

OECD Economic Survey Israel, March, 2018. Available at: file:///C:/Users/Yuval/Downloads/OECD\%20Economic\%20Survey\%20Israel\%20Overview\%20 March\%202018\%20(1).pdf (Last accessed at May 23, 2020).

Office of the Registrar General \& Census Commissioner, India: West Bangai.

O'Sullivan, Arthur. Urban Economics, Eight Edition (2012). McGraw Hills International Edition.

Papke, L. E., and J. M. Wooldridge. Econometric methods for fractional response variables with an application to 401(k) plan participation rates. Journal of Applied Econometrics 11 (1996): 619632.

Schroeder, Larry D.; Sjoquist, David L.; Stephan, Paula E. (1986). Understanding Regression Analysis. Sage Publications. pp. 31-32. ISBN_0-8039-2758-4. 
Schmitt-Grohé, Stephanie; Teoh, Ken \& Martín Uribe, 2020. "Covid-19: Testing Inequality in New York City," NBER Working Papers 27019, National Bureau of Economic Research, Inc.

Vittinghoff E, Glidden DV, Shiboski SC, McCulloch CE. Regression Methods in Biostatistics: Linear, Logistic, Survival, and Repeated Measures Models. New York, NY: Springer Publishing Co; 2005. 75-76.

Wooldridge, J. M. Econometric Analysis of Cross Section and Panel Data. 2nd ed. Cambridge, MA: MIT Press (2010).

World Health Organization (WHO): Coronavirus. Available at: https://www.who.int/healthtopics/coronavirus\#tab=tab_1 (Last accessed at May 3, 2020). 
Table 1: Descriptive Statistics:

\begin{tabular}{|l|l|c|c|c|c|}
\hline Variable & Description & Mean & SD & Min & Max \\
\hline INFECTED & $\begin{array}{l}\text { Ratio between coronavirus } \\
\text { infected and total population }\end{array}$ & $210.90 \cdot 10^{-5}$ & $233.64 \cdot 10^{-5}$ & $24.65 \cdot 10^{-5}$ & $1,463.32 \cdot 10^{-5}$ \\
\hline POP_DENSITY & $\begin{array}{l}\text { Population density of the city } \\
\text { measured as persons per } \\
\text { square kilometer }\end{array}$ & $4,397.17$ & $4,223.07$ & 67 & 26,512 \\
\hline SOCIO_ECONOMIC & $\begin{array}{l}\text { Economic and socio- } \\
\text { demographic ranking of the } \\
\text { city on a scale between 1=the } \\
\text { worst; 10=the best }\end{array}$ & 5.0105 & 2.3497 & 1 & 9 \\
\hline Gini coefficient of inequality \\
in cities
\end{tabular}

Figure 1: Box Plots of Normalized Variables

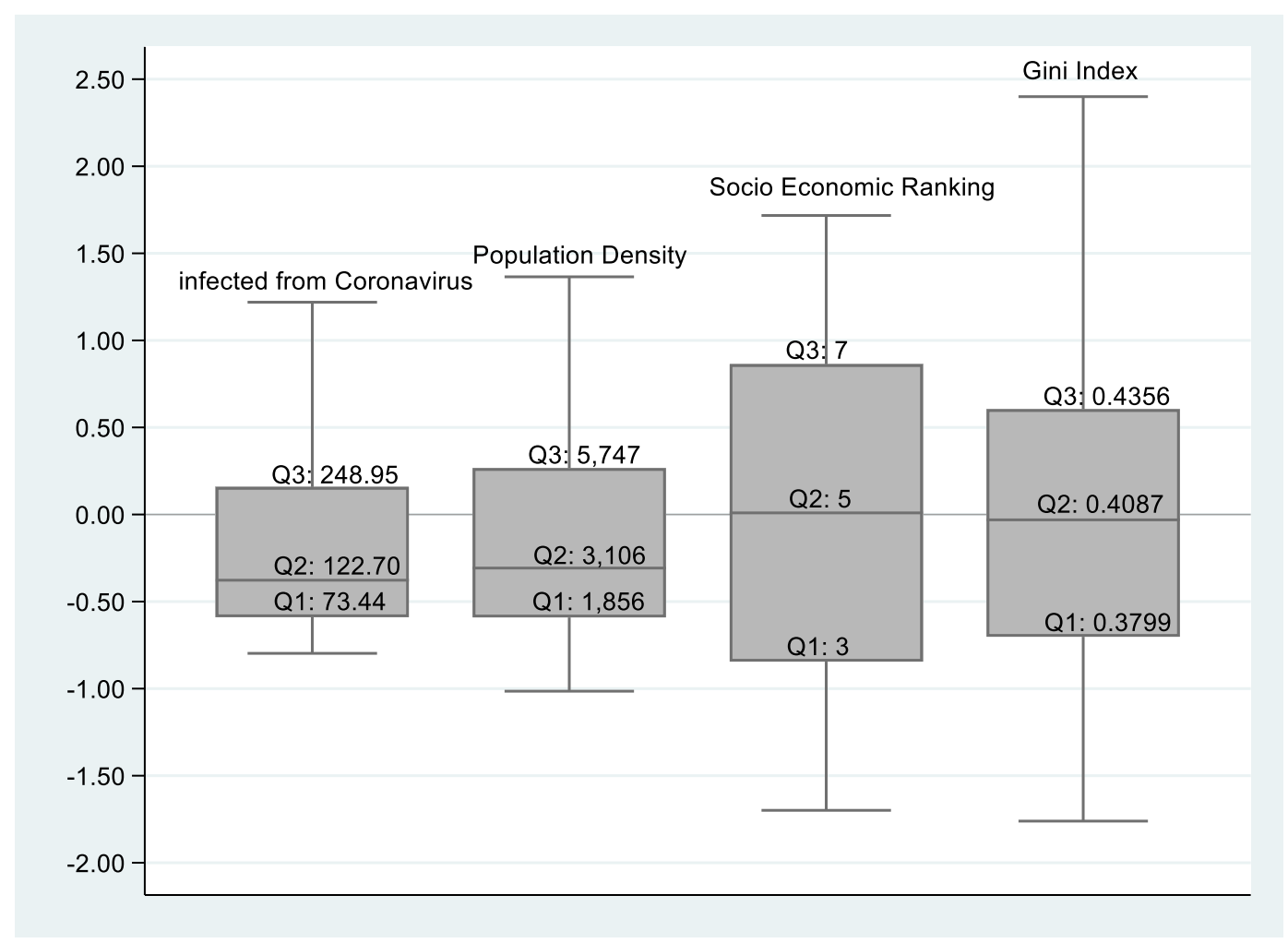

Notes: The table and figure refer to 95 main Israeli cities and settlements (including Tel Aviv, Haifa and Jerusalem) for which information based on the three indices is available, and with at least 15 infected from coronavirus disease. 
Table 2: Regression Analysis

\begin{tabular}{|c|c|c|c|c|}
\hline $\begin{array}{l}\text { Method } \\
\text { VARIABLES }\end{array}$ & $\begin{array}{c}\text { (1) } \\
\text { Fractional Probit } \\
\text { INFECTED }\end{array}$ & $\begin{array}{c}\text { (2) } \\
\text { LPM } \\
\text { INFECTED }\end{array}$ & VARIABLES & $\begin{array}{c}\text { (3) } \\
\text { OLS } \\
\mathbb{Z}(\text { INFECTED })\end{array}$ \\
\hline Constant & $\begin{array}{l}-3.499 * * * \\
(<0.0001)\end{array}$ & $\begin{array}{c}-0.00369 \\
(0.115)\end{array}$ & Constant & $\begin{array}{c}\text { NA } \\
(0.115)\end{array}$ \\
\hline POP_DENSITY & $\begin{array}{c}1.80 \cdot 10^{-5 * * *} \\
\left(6.32 \cdot 10^{-6}\right)\end{array}$ & $\begin{array}{c}2.18 \cdot 10^{-7 * * *} \\
\left(5.21 \cdot 10^{-6}\right)\end{array}$ & $\mathbb{Z}\left(P O P \_D E N S I T Y\right)$ & $\begin{array}{c}0.3941^{* * *} \\
\left(5.21 \cdot 10^{-6}\right)\end{array}$ \\
\hline SOCIO_ECONOMIC & $\begin{array}{c}-0.0820 * * * \\
(<0.0001)\end{array}$ & $\begin{array}{c}-0.000653^{* * * *} \\
\left(7.30 \cdot 10^{-8}\right)\end{array}$ & $\mathbb{Z}\left(S O C I O \_E C O N O M I C\right)$ & $\begin{array}{c}-0.6563^{* * * *} \\
\left(7.30 \cdot 10^{-8}\right)\end{array}$ \\
\hline GINI & $\begin{array}{c}2.255^{* * *} \\
(0.000742)\end{array}$ & $\begin{array}{c}0.0193 * * * \\
(0.00242)\end{array}$ & $\mathbb{Z}(G I N I)$ & $\begin{array}{r}0.3495 * * * \\
(0.00242) \\
\end{array}$ \\
\hline Observations & 95 & 95 & Observations & 95 \\
\hline R-squared & - & 0.398 & R-squared & 0.398 \\
\hline$\frac{1}{V I F}\left(P O P \_D E N S I T Y\right)$ & - & 0.9997 & $\operatorname{VIF}\left(P O P \_D E N S I T Y\right)$ & 1.00 \\
\hline$\frac{1}{V I F}($ SOCIO_ECONOMIC) & - & 0.5277 & VIF (SOCIO_ECONOMIC) & 1.90 \\
\hline$\frac{1}{V I F}(G I N I)$ & - & 0.5277 & VIF (GINI) & 1.90 \\
\hline$\frac{1}{V I F}($ Mean $)$ & - & 0.625 & VIF (Mean) & 1.60 \\
\hline
\end{tabular}

Notes: VIF (Variance Inflation Factor) is a measure for multicollinearity, where $\frac{1}{V I F}=1-R^{2}$ for the three regressions between POP_DENSITY, SOCIO_ECONOMIC and GINI as the dependent variables against the remaining independent variables. $\mathbb{Z}\left(V_{i}\right)=\frac{V_{i}-\bar{V}}{\sigma_{V}}$ for $i=1,2,3, \cdots, 95$ where $\bar{V}, \sigma_{V}$ are the respective mean and standard deviation of the variable $V_{i}$. Robust $P$-values are given in parentheses. $* p<0.1 ; * * p<0.05 ; * * * p<0.01$ 
Figure 2: Infected-Population Rate vs. Population Density

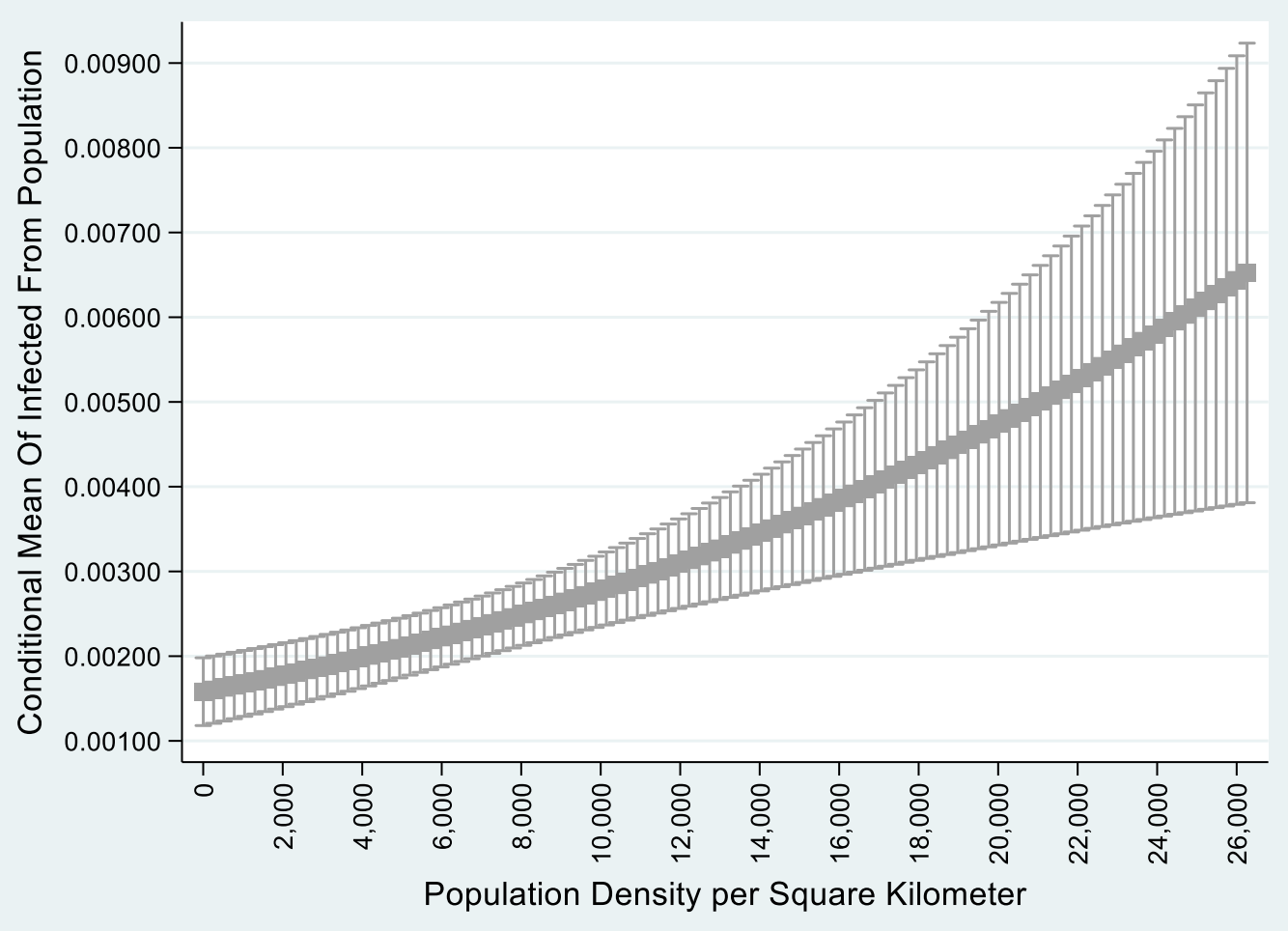

Figure 3: Infected-Population Rate vs. Socio- Demographic Ranking of the City

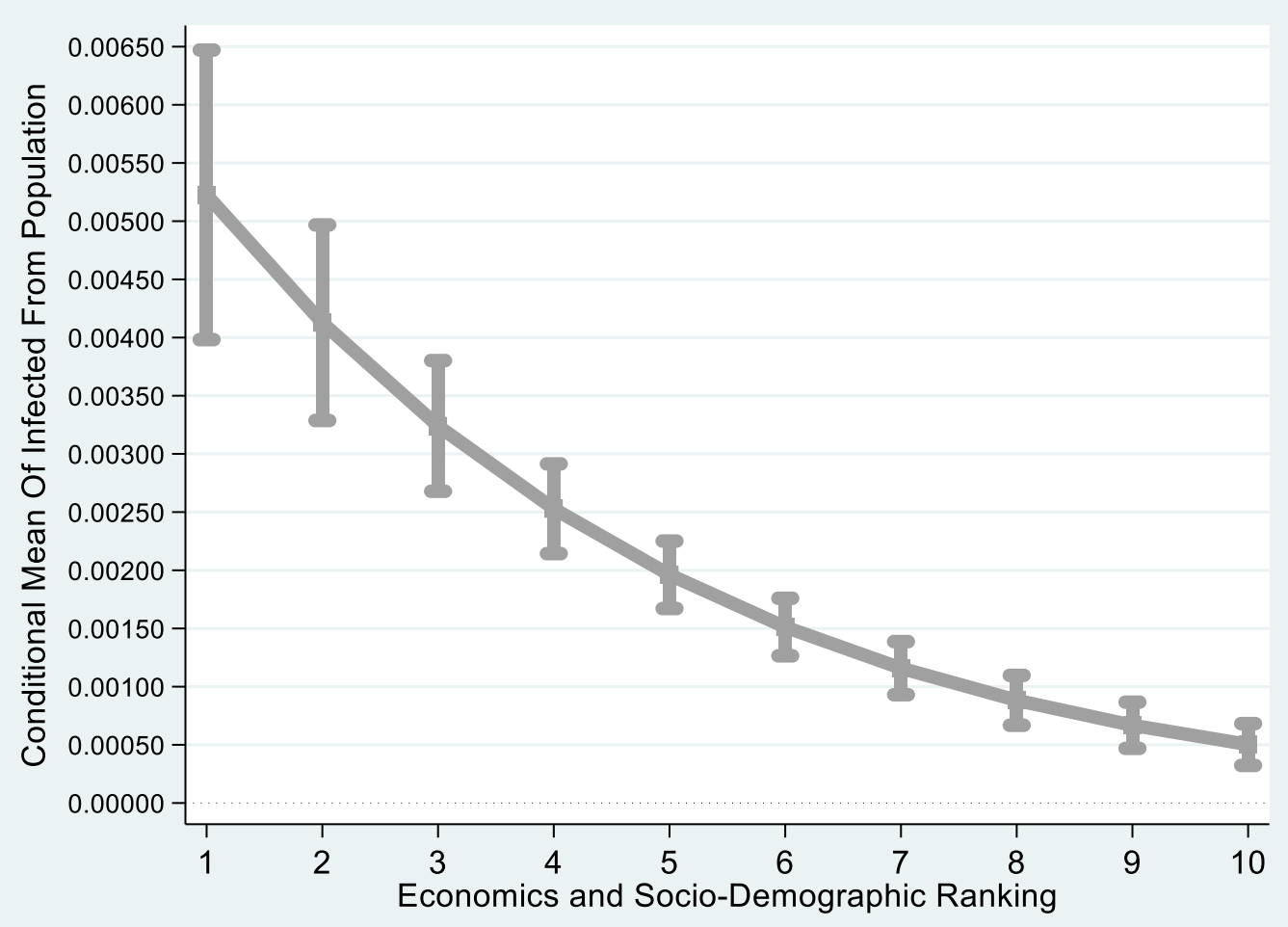


Figure 4: Infected-Population Rate vs. Gini Index

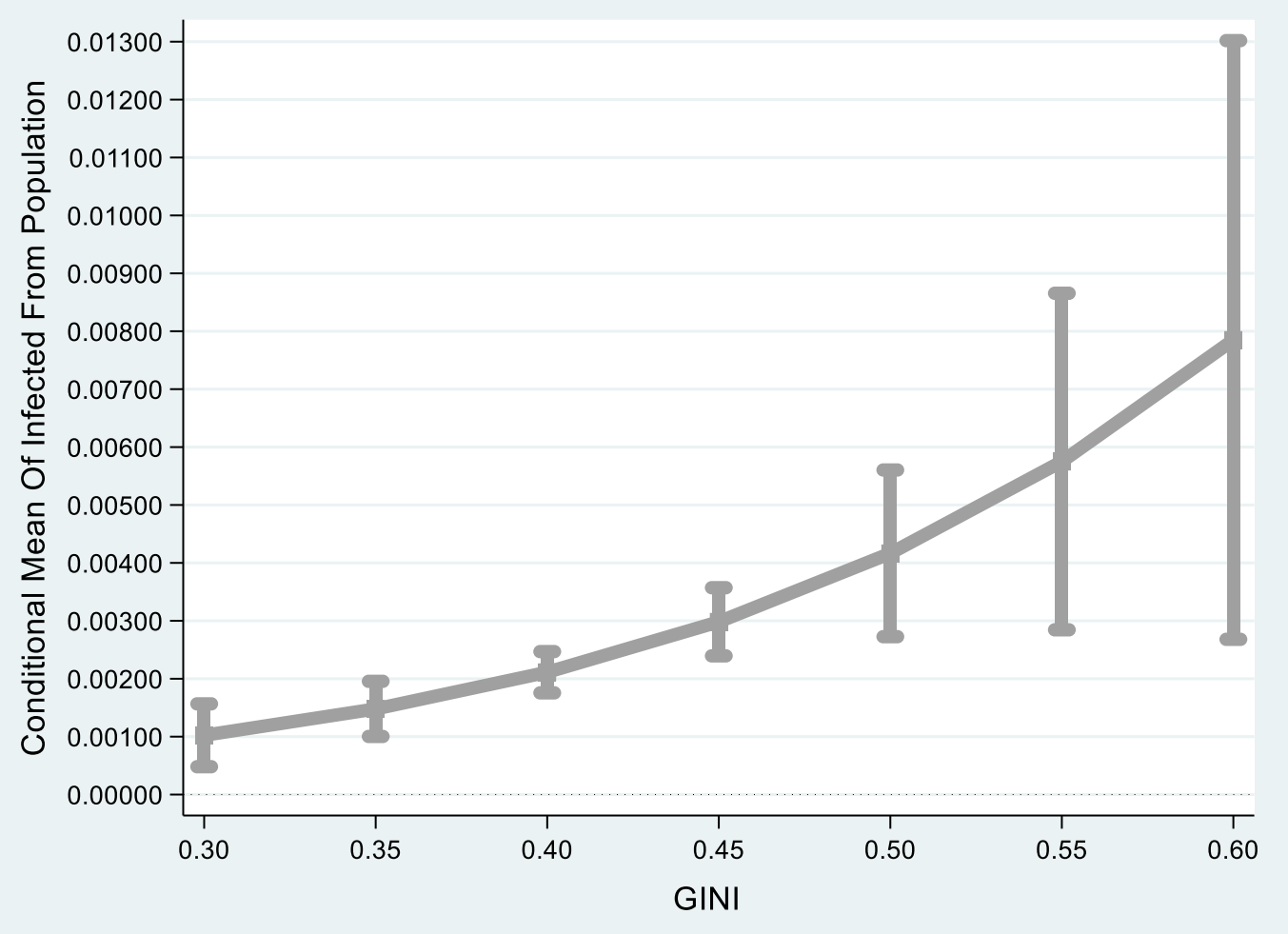

Notes: Figures 2, 3 and 4 are based on the regression outcomes given in coulmn (1) of Table (2). The vertical axis in each figure reflects the projected probability to be infected from coronavirus disease after trasformation of the coefficients and their $95 \%$ confidence intervals. The horizonal axis in each figure is based on the on sample values of the variables. 
Appendix: Descriptive Statistics Stratified by Cities and Settlements in Israel

\begin{tabular}{|c|c|c|c|c|c|c|c|}
\hline Number & $\begin{array}{l}\text { Cities and } \\
\text { Settlements }\end{array}$ & $\begin{array}{c}\text { Population } \\
\text { Rank-Size } \\
\text { Distribution }\end{array}$ & $\begin{array}{c}\text { Population } \\
\text { (2018) }\end{array}$ & $\begin{array}{c}\text { Infected } \\
\text { from } \\
\text { Population }\end{array}$ & $\begin{array}{c}\text { Population } \\
\text { Density }\end{array}$ & $\begin{array}{l}\text { Socio- } \\
\text { Economic } \\
\text { Ranking }\end{array}$ & Gini Index \\
\hline 1 & Jerusalem & 1 & 919,438 & 0.0039742 & 7,186 & 2 & 0.431 \\
\hline 2 & Tel Aviv & 2 & 451,523 & 0.001227 & 8,565 & 8 & 0.4773 \\
\hline 3 & Haifa & 3 & 283,640 & 0.0006029 & 4,346 & 7 & 0.4745 \\
\hline 4 & Rishon LeTsion & 4 & 251,719 & 0.000874 & 4,246 & 7 & 0.4202 \\
\hline 5 & Petach Tikva & 5 & 244,275 & 0.0011954 & 6,730 & 7 & 0.4204 \\
\hline 6 & Ashdod & 6 & 224,628 & 0.0012777 & 4,832 & 5 & 0.4169 \\
\hline 7 & Netanya & 7 & 217,244 & 0.0008194 & 7,373 & 6 & 0.4252 \\
\hline 8 & Be'er Sheva & 8 & 209,002 & 0.0008899 & 1,770 & 5 & 0.4303 \\
\hline 9 & Benei Berak & 9 & 198,863 & 0.0146332 & 26,512 & 2 & 0.4043 \\
\hline 10 & Holon & 10 & 194,273 & 0.000942 & 10,105 & 7 & 0.4043 \\
\hline 11 & Ramat Gan & 11 & 159,159 & 0.0012001 & 9,530 & 8 & 0.4448 \\
\hline 12 & Rehovot & 12 & 141,579 & 0.00089 & 5,835 & 7 & 0.4364 \\
\hline 13 & Ashkelon & 13 & 140,968 & 0.0018657 & 3,000 & 5 & 0.4117 \\
\hline 14 & Bat Yam & 14 & 128,774 & 0.00139 & 15,772 & 5 & 0.3649 \\
\hline 15 & Beit Shemesh & 15 & 118,676 & 0.0043733 & 2,958 & 2 & 0.4336 \\
\hline 16 & Kefar Saba & 16 & 100,763 & 0.0007344 & 6,897 & 8 & 0.4588 \\
\hline 17 & Herzeliya & 17 & 95,142 & 0.0011141 & 4,318 & 8 & 0.4897 \\
\hline 18 & Hadera & 17 & 95,683 & 0.000533 & 1,856 & 6 & 0.4073 \\
\hline 19 & Modiin & 19 & 92,406 & 0.0013094 & 1,889 & 8 & 0.4346 \\
\hline 20 & Nazareth & 20 & 77,064 & 0.0002465 & 5,417 & 3 & 0.3882 \\
\hline 21 & Ramla & 21 & 75,538 & 0.0008075 & 6,282 & 4 & 0.3478 \\
\hline 22 & Lod & 22 & 75,726 & 0.0011753 & 6,170 & 3 & 0.3597 \\
\hline 23 & Raanana & 23 & 73,999 & 0.0019054 & 4,912 & 8 & 0.4958 \\
\hline 24 & Modi' in Illit & 24 & 73,080 & 0.0056513 & 14,513 & 1 & 0.3846 \\
\hline 25 & Rahat & 25 & 69,032 & 0.0009126 & 3,403 & 1 & 0.3356 \\
\hline 26 & Hod Hasharon & 27 & 62,325 & 0.0006899 & 3,149 & 8 & 0.4742 \\
\hline 27 & Givaataim & 28 & 60,212 & 0.0007141 & 18,308 & 8 & 0.4377 \\
\hline 28 & Kiryat Ata & 29 & 58,267 & 0.0004291 & 3,523 & 6 & 0.4127 \\
\hline 29 & Beitar I'lit & 32 & 56,746 & 0.005181 & 11,098 & 1 & 0.3781 \\
\hline 30 & Umm al Fahm & 33 & 55,182 & 0.0014497 & 2,080 & 2 & 0.3846 \\
\hline 31 & Kiryat Gat & 34 & 54,973 & 0.0009823 & 3,363 & 4 & 0.3737 \\
\hline 32 & Eilat & 35 & 51,935 & 0.0004814 & 513 & 6 & 0.3662 \\
\hline 33 & Rosh Ha'ain & 36 & 56,344 & 0.0009584 & 3,188 & 7 & 0.4199 \\
\hline 34 & Afula & 37 & 51,737 & 0.0012564 & 1,679 & 5 & 0.3946 \\
\hline 35 & Nes Ziona & 38 & 50,214 & 0.000478 & 3,121 & 8 & 0.4356 \\
\hline 36 & Acre & 39 & 48,930 & 0.0005722 & 3,387 & 4 & 0.3785 \\
\hline 37 & El'ad & 40 & 47,866 & 0.0080851 & 13,516 & 2 & 0.3895 \\
\hline 38 & Ramat Hasharon & 41 & 46,720 & 0.001006 & 2,768 & 9 & 0.5167 \\
\hline 39 & Karmiel & 42 & 46,124 & 0.0011491 & 2,093 & 6 & 0.4087 \\
\hline 40 & Yavne & 43 & 46,705 & 0.0008136 & 2,790 & 7 & 0.4177 \\
\hline 41 & Tiberias & 44 & 44,234 & 0.0037754 & 2,684 & 4 & 0.395 \\
\hline 42 & Tayibe & 45 & 43,127 & 0.0011362 & 2,247 & 3 & 0.3814 \\
\hline 43 & $\begin{array}{l}\text { Pardes Hanna- } \\
\text { Karkur }\end{array}$ & 48 & 42,083 & 0.0004277 & 1,825 & 7 & 0.4445 \\
\hline
\end{tabular}




\begin{tabular}{|c|c|c|c|c|c|c|c|}
\hline Number & $\begin{array}{l}\text { Cities and } \\
\text { Settlements }\end{array}$ & $\begin{array}{c}\text { Population } \\
\text { Rank-Size } \\
\text { Distribution }\end{array}$ & $\begin{array}{c}\text { Population } \\
(2018)\end{array}$ & $\begin{array}{c}\text { Infected } \\
\text { from } \\
\text { Population }\end{array}$ & $\begin{array}{c}\text { Population } \\
\text { Density }\end{array}$ & $\begin{array}{c}\text { Socio- } \\
\text { Economic } \\
\text { Ranking }\end{array}$ & Gini Index \\
\hline 44 & Nof Hagalil & 51 & 41,169 & 0.0008016 & 1,230 & 5 & 0.3848 \\
\hline 45 & Kiriat Yam & 52 & 39,909 & 0.0007267 & 8,668 & 5 & 0.3975 \\
\hline 46 & Kiryat Bialik & 53 & 39,927 & 0.0004258 & 4,675 & 7 & 0.4203 \\
\hline 47 & Kiryat Ono & 54 & 39,986 & 0.0013005 & 8,678 & 8 & 0.4584 \\
\hline 48 & Ma'ale Adumim & 56 & 38,193 & 0.0013615 & 813 & 6 & 0.3857 \\
\hline 49 & Or Yehuda & 57 & 36,864 & 0.0039334 & 5,478 & 6 & 0.392 \\
\hline 50 & Zefat & 58 & 35,715 & 0.002016 & 1,177 & 2 & 0.4245 \\
\hline 51 & Netivot & 59 & 35,631 & 0.0028346 & 3,330 & 3 & 0.3876 \\
\hline 52 & Dimona & 60 & 34,135 & 0.0008496 & 195 & 4 & 0.4258 \\
\hline 53 & Tamra & 61 & 33,851 & 0.0006499 & 1,139 & 2 & 0.3663 \\
\hline 54 & Sakhnin & 64 & 31,057 & 0.0005474 & 3,106 & 3 & 0.392 \\
\hline 55 & Yahud & 66 & 29,930 & 0.0026729 & 5,940 & 8 & 0.4496 \\
\hline 56 & $\begin{array}{l}\text { Baqa al- } \\
\text { Gharbiyye }\end{array}$ & 67 & 29,393 & 0.0006804 & 3,201 & 3 & 0.3685 \\
\hline 57 & Ofakim & 70 & 29,021 & 0.0015506 & 2,715 & 3 & 0.3799 \\
\hline 58 & Gedera & 71 & 28,092 & 0.0019579 & 2,410 & 7 & 0.4257 \\
\hline 59 & Givat Shmuel & 73 & 26,023 & 0.0016524 & 10,118 & 8 & 0.4579 \\
\hline 60 & Arad & 75 & 26,451 & 0.0007183 & 249 & 4 & 0.4206 \\
\hline 61 & Migdal Ha'emek & 76 & 25,636 & 0.0038227 & 2,903 & 4 & 0.3758 \\
\hline 62 & Sderot & 77 & 26,455 & 0.0012096 & 3,984 & 5 & 0.3767 \\
\hline 63 & Mevaseret Zion & 80 & 23,962 & 0.000626 & 3,807 & 8 & 0.4716 \\
\hline 64 & Gan Yavne & 83 & 23,752 & 0.0011367 & 2,054 & 7 & 0.416 \\
\hline 65 & Zichron Yaakov & 87 & 23,075 & 0.0016035 & 728 & 8 & 0.5097 \\
\hline 66 & Beer Yaakov & 88 & 26,122 & 0.0008422 & 2,663 & 7 & 0.3796 \\
\hline 67 & Kiryat Shemona & 89 & 22,625 & 0.000663 & 1,566 & 5 & 0.3746 \\
\hline 68 & Yokneam Ilit & 90 & 23,311 & 0.0007293 & 2,765 & 7 & 0.4185 \\
\hline 69 & Kefar Kasem & 90 & 23,241 & 0.0007315 & 2,423 & 3 & 0.3497 \\
\hline 70 & Kefar Yona & 92 & 23,060 & 0.0006938 & 1,984 & 7 & 0.4193 \\
\hline 71 & Kiryat Mal'achi & 94 & 23,124 & 0.0024217 & 4,912 & 3 & 0.3615 \\
\hline 72 & Kadima-Zoran & 96 & 22,490 & 0.000667 & 2,151 & 8 & 0.4581 \\
\hline 73 & Kefar Kenna & 96 & 22,399 & 0.0007143 & 2,189 & 2 & 0.3864 \\
\hline 74 & Tirat Ha'carmel & 98 & 22,210 & 0.0008104 & 3,598 & 5 & 0.3862 \\
\hline 75 & Shoham & 100 & 20,990 & 0.0016675 & 2,903 & 9 & 0.4585 \\
\hline 76 & Hura & 101 & 21,558 & 0.0063549 & 2,388 & 1 & 0.345 \\
\hline 77 & Ganei Tikva & 111 & 19,263 & 0.0024399 & 8,667 & 8 & 0.4558 \\
\hline 78 & Givat Ada & 116 & 17,922 & 0.0030131 & 3,879 & 5 & 0.4178 \\
\hline 79 & Ar'ara (Negev) & 119 & 17,640 & 0.0013039 & 1,217 & 1 & 0.347 \\
\hline 80 & Majed-El-Krum & 124 & 15,292 & 0.0013079 & 1,624 & 2 & 0.3489 \\
\hline 81 & Jisr az-Zarqa & 128 & 14,692 & 0.0029948 & 8,944 & 2 & 0.2745 \\
\hline 82 & Even Yehuda & 132 & 13,700 & 0.0022628 & 1,661 & 8 & 0.4987 \\
\hline 83 & Azur & 144 & 12,854 & 0.0024895 & 5,747 & 7 & 0.3925 \\
\hline 84 & Dir-El-Asad & 147 & 12,348 & 0.0123097 & 2,300 & 3 & 0.3723 \\
\hline 85 & Rechasim & 150 & 12,110 & 0.0033031 & 3,631 & 2 & 0.4277 \\
\hline 86 & Gat & 152 & 11,798 & 0.0019495 & 1,650 & 4 & 0.3812 \\
\hline 87 & Efrat & 171 & 10,088 & 0.0063442 & 1,402 & 6 & 0.4622 \\
\hline 88 & Ba'ana & 180 & 8,299 & 0.0040969 & 2,362 & 2 & 0.3792 \\
\hline
\end{tabular}




\begin{tabular}{|l|l|c|c|c|c|c|c|}
\hline Number & $\begin{array}{l}\text { Cities and } \\
\text { Settlements }\end{array}$ & $\begin{array}{c}\text { Population } \\
\text { Rank-Size } \\
\text { Distribution }\end{array}$ & $\begin{array}{c}\text { Population } \\
(2018)\end{array}$ & $\begin{array}{c}\text { Infected } \\
\text { from } \\
\text { Population }\end{array}$ & $\begin{array}{c}\text { Sopulation } \\
\text { Density }\end{array}$ & $\begin{array}{c}\text { Socio- } \\
\text { Economic } \\
\text { Ranking }\end{array}$ & Gini Index \\
\hline 89 & Kazrin & 199 & 7,132 & 0.0021032 & 757 & 5 & 0.3747 \\
90 & Pki'in (Buke'ia) & 215 & 5,815 & 0.0025795 & 1,007 & 5 & 0.3966 \\
91 & Mizpe Ramon & 219 & 5,221 & 0.0049799 & 67 & 3 & 0.4101 \\
92 & Kiryat Yearim & 224 & 5,565 & 0.0070081 & 9,600 & 2 & 0.4379 \\
93 & Yavneel & 226 & 4,294 & 0.0041919 & 138 & 3 & 0.4624 \\
94 & Harish & 234 & 7,569 & 0.0021139 & 514 & 3 & 0.3979 \\
95 & Immanuel & 239 & 3,693 & 0.0040617 & 675 & 2 & 0.381 \\
\hline
\end{tabular}

Notes: The sample includes 95 cities and settlements in Israel. Cities and settlements with fewer than 15 infected persons were excluded from the sample. 
Figures

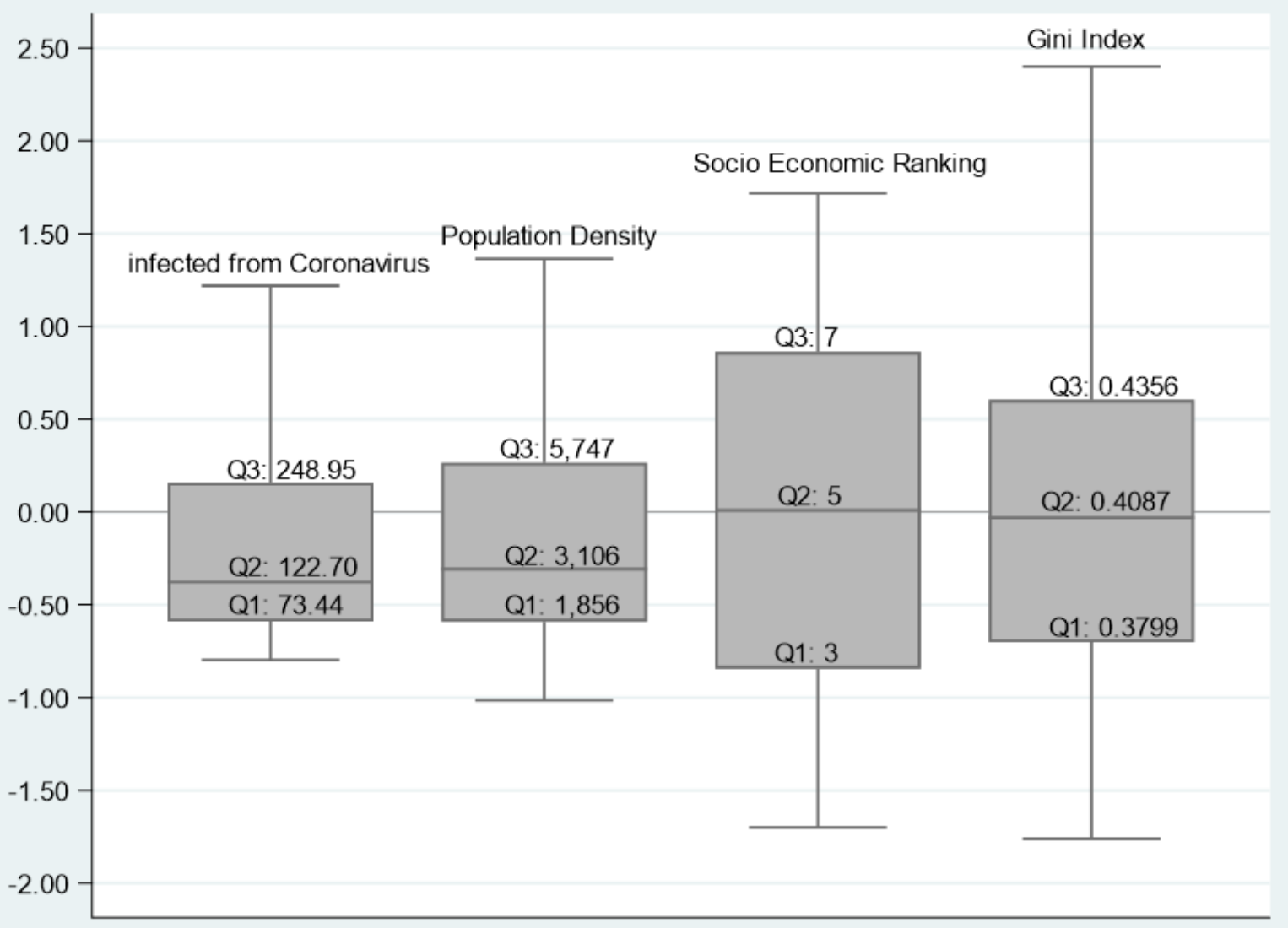

Notes: The table and figure refer to 95 main Israeli cities and settlements (including Tel Aviv, Haifa and Jerusalem) for which information based on the three indices is available, and with at least 15 infected from coronavirus disease.

Figure 1

Box Plots of Normalized Variables 


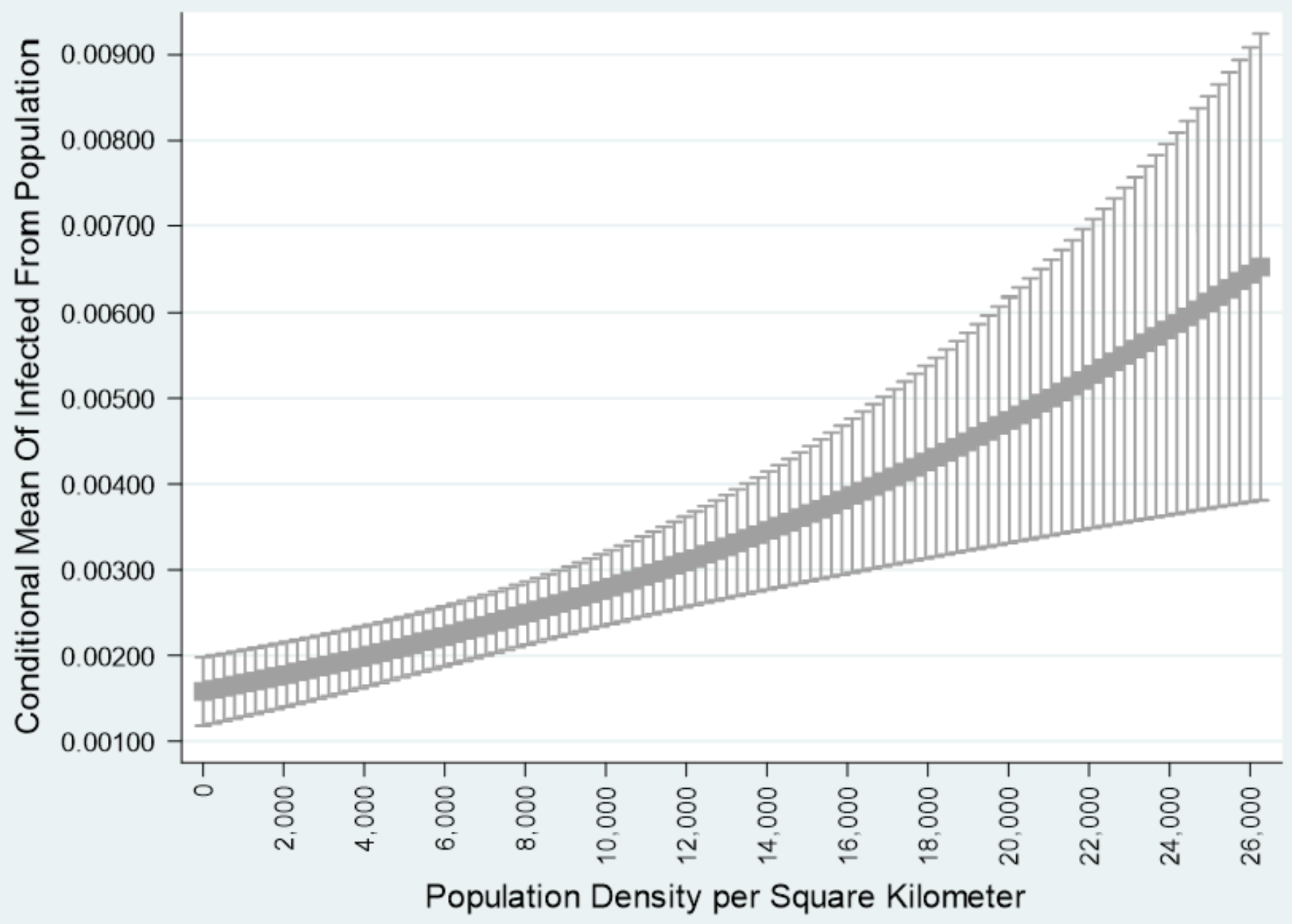

Figure 2

Infected-Population Rate vs. Population Density 


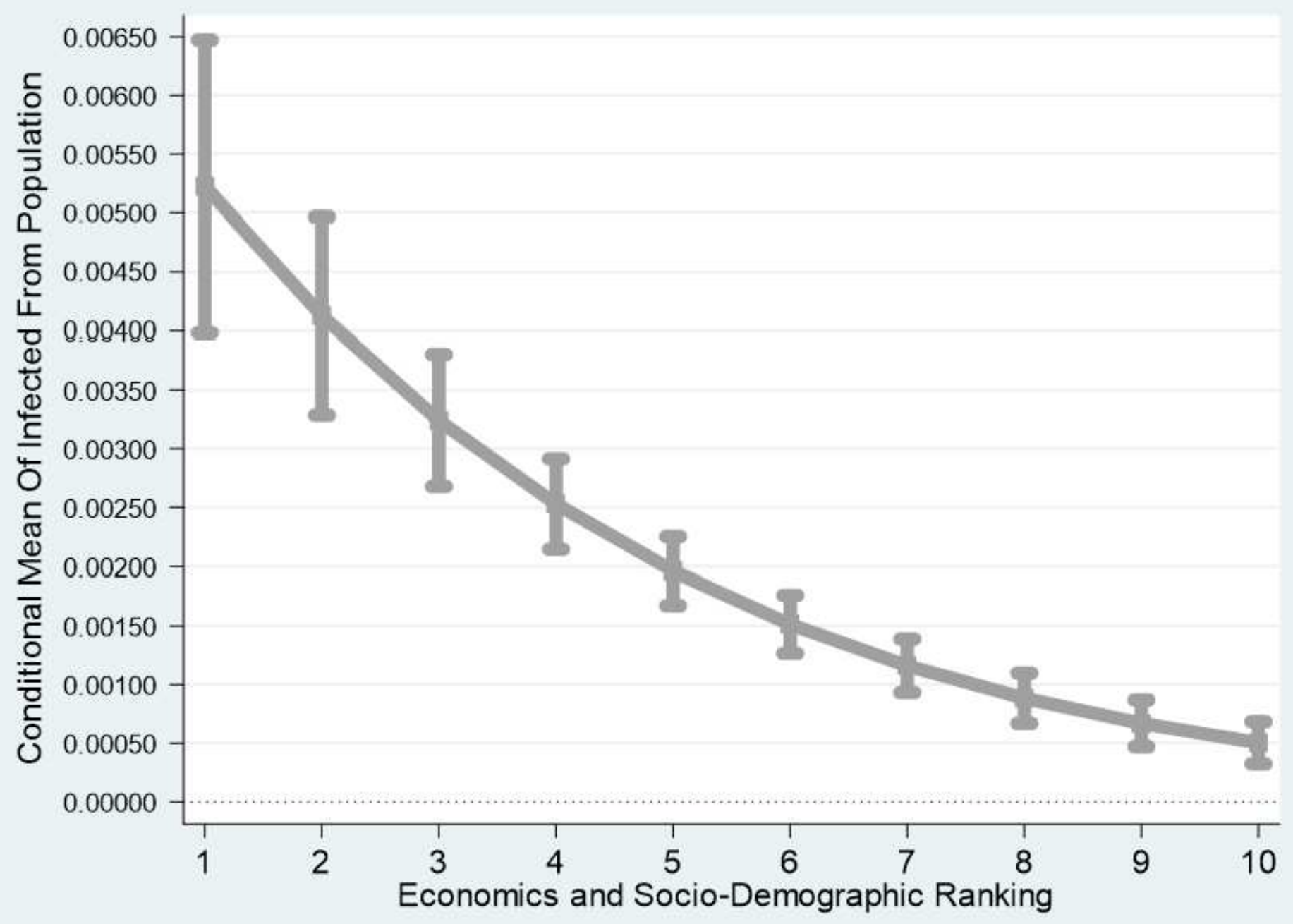

Figure 3

Infected-Population Rate vs. Socio- Demographic Ranking of the City 


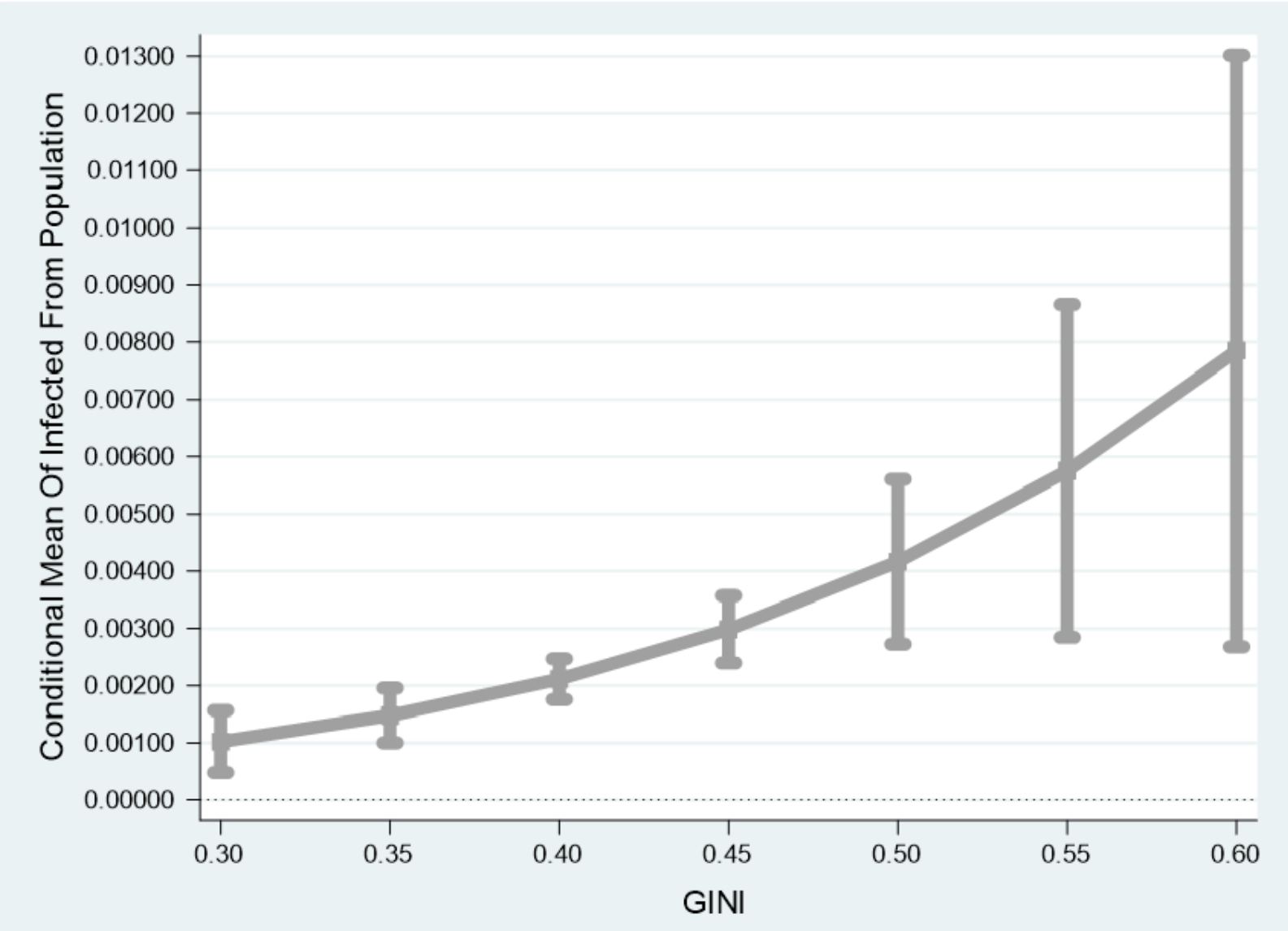

Notes: Figures 2, 3 and 4 are based on the regression outcomes given in coulmn (1) of Table (2). The vertical axis in each figure reflects the projected probability to be infected from coronavirus disease after trasformation of the coefficients and their $95 \%$ confidence intervals. The horizonal axis in each figure is based on the on sample values of the variables.

\section{Figure 4}

Infected-Population Rate vs. Gini Index

\section{Supplementary Files}

This is a list of supplementary files associated with this preprint. Click to download.

- Appendix.docx 